Article

\title{
An Interpretative Matrix for an Adaptive Design Approach. Italian School Infrastructure: Safety and Social Restoration
}

\author{
Roberta Ingaramo *(D) and Luca Pascale \\ Department of Architecture and Design, Politecnico di Torino, Castello del Valentino, viale Mattioli 39, \\ 10125 Turin, Italy; pascal8405@gmail.com \\ * Correspondence: roberta.ingaramo@polito.it
}

Received: 10 August 2020; Accepted: 2 October 2020; Published: 11 October 2020

\begin{abstract}
The Italian school infrastructure has suffered in recent decades from an immobility that has generated critical issues and shortcomings in the management of structures, safety adjustments, and innovations in the architectural and pedagogical model. This type of stasis, due to the scarcity of resources on a national scale and the decrease in the birth rate of the country, has meant that the buildings are largely inadequate from both a regulatory and socio/pedagogical point of view, with a level of degradation that is leading to a progressive abandonment of several structures, generating further insecurity at the urban level. In Italy, the current health emergency (SARS-CoV-2), with the necessity of wider spaces for social distancing and less numerous classes, has further highlighted the strongly problematic nature of an extensive and often obsolete school building heritage, raising the need to reevaluate heritage in terms of safety, accessibility, economic impact, and, last but not least, social cohesion. The paper proposes an approach that starts from the analysis of regulations and data on a national scale related to the structural and formal conditions of school buildings, interpreting and evaluating their safety with a holistic approach, to then proceed to the definition of a design survey matrix able to classify the selected cases and give an interpretative reading that includes the vastest number of characterizing factors. The Italian territory (between Abruzzo, Lazio, and Umbria) affected by the 2016 and 2017 earthquakes has been selected as a significant case study due to its obvious conditions of further criticality for the formulation of an evaluation methodology through an extensive field survey, cross-referenced with available data on the resilience of school structures and their role in the urban fabric, with the ultimate aim of identifying functional methods for their adaptation to a contemporary, safe, flexible, and shared school model with local communities.
\end{abstract}

Keywords: school infrastructure safety; design investigation methods; urban resilience; civic center; social landmark

\section{Introduction}

When a country has to deal with the consequences of an event that profoundly affects its territory and its inhabitants, be it situations of war or natural disasters, the first actions needed to bring peace between the state and local communities and to support the populations affected by the crisis situation are concentrated on the rehabilitation of public buildings, their "securing", and the reactivation of the services they provide. Re-establishing a series of essential and primary services that the state must take responsibility for is a fundamental condition for reactivating a perception of normality, livability, and social security in local populations. In this context, schools and their spaces are the symbol of a promising future, and are also depositories of a recovery in the provision of public services; it is in spaces such as schools that the community places its trust in the future of its territory and its economy. 
The research that we are going to illustrate investigates spatial qualitative characteristics suggested by the new pedagogical models, which establish a close relationship between architecture and pedagogy, with a dependence between the quality of learning spaces and the quality of learning, taking into account the INDIRE (National Institute for Documentation, Innovation, and Educational Research, founded in 1926 in Italy) manifesto, which, through the Avanguardie educative (Educational Avant-garde) movement of innovation, systematizes the most significant transformation experiences of the schools' organizational and teaching model, today conceived as the Civic Center, a multifunctional social gathering place that is open beyond school hours with cultural and recreational activities [1].Our research identifies a series of characterizing principles to start from for a survey that is not only quantitative, but also qualitative, in addition to Alexander's "quality without a name" [2,3], of a selected sample of school buildings located in those territories that have been called "territories of the earthquake crater", included in the Italian regions of Abruzzo, Lazio, Marche and Umbria [4].

The interpretations of the quality of this sample and the relations that are established with the urban metabolism of the respective contexts are essential elements to complete the survey. The expansion of the meaning of the term security (not only structural), which the design field of architecture and urban design incorporates in its specific research modalities, can provide a multi-faceted vision of the theme, with the aim of identifying possible strategies of formal transformation based on qualitative parameters selected on the basis of the analytical-cognitive phase of the survey. The data are then systematized through a matrix - an interpretative tool to identify possible transformations to be implemented-that responds to a high qualitative demand that assimilates many other definitions into the term itself, such as sustainability.

Resilient and sustainable cities [5,6], terms already mentioned in the book produced at the Oliphant conference in Melbourne in 2011, are full of different definitions by the many authors of the 26 chapters [7]; smart cities and buildings [8], infrastructural and structural urban security $[9,10]$, social equality [11] are just some of the great mantras that we find behind scientific research, but especially in the policies that manage it, such as the European research and innovation program Horizon 2020 [12], which has provided 80 billion euros for sustainable growth consistent with European strategies.

The definition of choices that are consistent with the objectives of sustainability—or rather quality, a term that is also abused and difficult to define- to which architects are urgently turning derive from the need to establish at least some guidelines that can protect a certain architectonic and urban quality (in Italy, the guidelines for architectural quality are being approved by Mibact, the Ministry of Cultural Heritage, Activities, and Tourism, and Cnappc, the National Council of Architects, Planners, Landscape Architects, and Conservationists). These objectives set by the political agendas of states and the European Community are crucial to formulate survey methodologies that take into account the different variables (such as the possibility of social interrelation within the school and between school and the urban environment, the perception of security, the relationship between nature and architecture, etc.) so as not to restrict the identification of qualitative parameters in purely quantitative formulations determined by economic assessments, such as the use of the Life Cycle Assessment approach, certifications such as LEED rating system of the American Green Building Council, or impacts and indices calculated by sophisticated software [13].

However, the qualitative dimension also has a decisive weight on the perception of security, which can be interpreted at a personal level (safety) or as a circumstance that occurs at a social level (security), taking into account the condition of maintaining the state of security, which is essential for a community and also influences the relative real estate values of the neighborhoods that make up a city. The use and abuse of the two terms in common language is verified by scientific research [14,15], as well as in the scientific literature analyzed by psychologists, philosophers, and criminologists [16]. It was found that safety of the urban environment and urban security are among the most frequently repeated categories in the examined literature, which mainly concerns social and humanitarian aspects, always underestimating the issue of the perception of security. The dimension of social and personal insecurity produced by the SARS-CoV-2 pandemic has required a review and redefinition of the qualitative 
parameters of our urban dimension, of its built and unbuilt spaces, in relation to the modified needs, such as social distancing and adjusted social interaction, with the aim of finding strategies capable of restoring a renewed perception of security.

Knowing how to read the dimension of the project is the field of architects, whose aim is always and in any case the project of change, transformation, and even minimal modifications in formal terms, but, from a qualitative and impact point of view, still relevant to the urban and territorial dimension and to local communities in social and economic terms.

By taking into account the institutional surveys conducted by the state or foundations (such as Fondazione Agnelli) in the Italian territory that are circumscribed to a collection of quantitative data, and then possibly assuming single projects, we have constructed an interpretative matrix that correlates the qualitative data identified through a field survey to formulate replicable transformation solutions.

The interpretative design reading, developed through the filter of a specifically created survey matrix that is useful for categorizing the necessary interventions, is applied to a series of case studies-a defined number of Italian schools in a state of physical and functional degradation-to test their effectiveness in supporting the pinpointing of design strategies capable of making a change, transforming these public buildings into spaces of social, innovative, and inclusive gathering, and identification.

\section{Architecture and Urban Design as a Tool for Transformation}

The survey proposed herein was conducted through the lens of the disciplines of project design (interior design, architecture, urban design, landscape design)—from the French projeter, which derives from late Latin proiectare, to throw ahead [17]—as a foreshadowing of future transformation capable of building infinite different scenarios, and as a miscellany of knowledge of which the project is an interpretative synthesis, a diachronic process constructed through questioning, revisions, and negotiations between the architect, their collaborators, and the client [18] — not a negotiation between different actors and material objects $[19,20]$, but a negotiation between actors, objects, and their embodied histories [21].

The project provides a holistic vision of complex issues both in the field of the profession where the architect is primarily the coordinator of a team of experts from increasingly different disciplines, and in that of scientific research, where architecture needs the contribution of different disciplines to archive the final project (technologies, structures, physics, sociology, planning, etc.). When Vitruvius [22] wrote his treatise, he tried to give instruments and rules to the discipline by defining its field, as did Leon Battista Alberti in the most important Renaissance treatise [23], which redraws its more precise boundaries. All subsequent theoretical writings from Viollett le Duc onwards have taken inspiration from the field definitions established in these treatises, extending their boundaries and modifying their possible interrelationships, such as the writings of Stan Allen, Peter Eisenman, Rem Koolhas, Sanford Kwinter, or Bernard Tshumi, to name but a few who have done so by using theoretical instruments [24].

The design approach provides a dimension of complexity made up of various factors, with formulations of multi-faceted cognitive and propositional hypotheses, precisely due to the characteristics of the discipline of architecture itself, whose boundaries appear increasingly uncertain and undefined, mixing with other disciplines such as sociology, literature, philosophy, politics, linguistics, biology, etc., with a disciplinary syntax to which belong values that influence how the context is taken into account, the information is collected and analyzed, and the criteria are selected to define the phases of a diachronic process, such as that of the project [24].

Architecture is changing on a daily basis into dynamic, flexible and even temporary spaces, rather than durable objects that occupy a permanent scene [25], and a large part of architectural research concentrates on spaces of intersection and mediation, which Aldo Van Eyck [26] already called intermediate places, or spaces in-between in Hertzberger [27] (p. 211), which are capable of restoring an articulation between spaces of different natures, allowing for greater intimacy, privacy, and perception of security. It is precisely in those thresholds, also imagined by the Smithsons [28], 
that private and public find a place of compromise that allows different uses, capable of flexibility according to individual needs, social distancing, or a return to sharing in small groups.

In his Open City [29], Sennett tells us that today's cities are not what we would like them to be: clean and safe, with efficient public services and with a dynamic economy, cultural liveliness, and social equity. So, it is precisely the vision of the project that prefigures this becoming through an assemblage of its parts [30] in an additive process [31], adaptable to single spatial situations, flexible, and incremental over time. These are the spaces of reuse where sustainability and opportunity merge in a resilient approach that reinitiates processes of re-appropriation of abandoned or underused spaces, buildings, and infrastructures. This dynamic vision that is typical of the project disciplines embodies a design strategy that requires flexible, incremental structures and infrastructures [32] made by architectures that include a vision of sustainability determined by adaptability, even temporary, which are capable of being a place of exchange, interaction, and variation.

\section{Reuse as an Architectural Tool}

Architecture, now as spatial and formal research, faces the challenge of overcoming the need to "change the existing environment", as Venturi and Scott Brown pointed out in the 1970s [33], to focus on enhancing what already exists. Reuse, in many cases, is a tool used to highlight the local identity of places and cities, and is recognized nowadays as a sustainable action with minimum changes to save embodied energies [34-39]. In these last years, the reduced financial resources that followed the crisis of 2008 and, now, the new economic crisis-a consequence of the pandemic-have made this design practice increasingly widespread, especially in Italy, also considering that the directives in Europe foresee zero soil consumption by 2050, as well as zero net land taking by 2050 [40]. Today, the challenge is "ordinary heritage", such as school buildings that need reconversion, or technical, morphological adaptation that can be conducted by reuse practice, which is considered a sustainable and economic practice $[41,42]$.

Most Italian school buildings are obsolete and need to be adapted to safety and energy standards, but above all, to new contemporary educational spatial parameters that imply substantial changes in their spaces; therefore, a reshaping of this heritage is reflected in initiatives to promote the transformation and adaptation of schools. The Fermi middle school in Turin, an old 1960s school, which was supposed to be demolished and rebuilt, was then renovated and is now an innovative reference model of this practice. It is new space for the community integrated into the urban context and defines new possibilities for the educational system, as described in the article in Domus (BDR bureau 2019, client Fondazione Agnelli, Compagnia di San Paolo, costs of construction: 7.3 million euros, surface: $\left.5579 \mathrm{~m}^{2}\right)$ [43].

It is in this framework that reuse becomes endemic practice, and in Italy, research tests ways for a widespread recycling of fabrics, infrastructures, and structures by giving it the name of Re-cycle, or Prin Re-Cycle Italy (funded by the Italian Ministry of Research and Education 2013-2016), which internationally clashes with the consolidated term of adaptive reuse, which is endorsed, as we have seen, in international literature. However, this completely Italian line of research confers a dimension to the term that presupposes the acceptance of the end of a lifecycle of artifacts or disused areas to open up to new founding principles, with design outcomes that identify new forms and spatiality [44-46] in order to presume the idea of an even substantial change, but by re-founding the remains in the same places (no soil consumption).

The architectural project assumes an organizational role of the system, identifying decisive elements with a particular focus on the reuse of space and detail, which become architecture together with retrofitting and regulatory adaptation, transforming works that were supposedly based on technical adaptations into an opportunity for formal redefinition that is capable of significant impacts on the territory. 


\section{Materials and Methods}

The pandemic situation (SARS-CoV-2) experienced in recent months has stressed issues that were already evident, but which have acquired strength and prominence, placing themselves today as an essential necessity to which not only contingent solutions can be given. Public buildings, such as schools, have long been the subject of investigations that highlight their inadequacy in terms of safety in many countries and in most European states, but especially where building heritage is already obsolete and inadequate compared to the renewed educational standards.

Even in the U.K., where schools are international reference points for their education system, the Department for Education's school condition data collection (CDC) launched a program [47] in early 2017 to investigate the condition and management of school buildings under government jurisdiction and maintenance. It highlighted that, among the buildings considered, "more than one in six schools in England required urgent repairs", and, as the Guardian pointed out, "investigation has found, leading to warnings, that they are crumbling around teachers and pupils." These are large quantities of buildings-about 4000-in immediate need of restoration, but a much larger number do not have the certifications required by current regulations, such as suitability of electrical systems, fire risk assessments, or asbestos management plans [48].

\section{Italian Schools}

In Italy, the situation of degradation of school buildings reflects bad management by the state-a symptom of a precarious balance between institution and community [49].

A picture that provides the available data confirms the need for urgent interventions in school heritage throughout the national territory (ANCE-CRESME; Cittadinanzattiva; Legambiente; Tuttoscuola). The data collected by Legambiente [50] confirm the seriousness of the situation: $36.7 \%$ of school buildings require urgent maintenance work, in line with what was reported in the ANCE-CRESME report, where about one-third of Italian public school buildings-about 15,000, and the total of which amount to 40,151-needed urgent safety interventions as of 2019, taking just the functional ones into account (ANCE-CRESME 2012).

Imparesicuri XVII Edition, a report presented by Cittadinanzattiva [51] (an Italian non-profit organisation founded in 1978), published in September 2019, reveals how the situation has further deteriorated despite the implementation of certain policies for the renovation of buildings. In the years 2018 and 2019, 70 collapses were recorded in school buildings, 29 of which were in Northern Italy, 17 in Central Italy, and 24 in the Southern regions and islands. Only 17 people were involved in the collapses, as these occurred mainly during school closing hours or periods, but from 2013 to date, there have been 276 episodes that highlight the seriousness of the state of degradation of the Italian school heritage.

The Anagrafe dell'Edilizia Scolastica (AES; National Registry of School Buildings) has been developed with open data by the MIUR, the Italian Ministry of Education, Universities, and Research, to make the data relating to each individual school transparent and public through the portal of the MIUR so as to be able to promptly identify buildings in need of immediate intervention. This is a form of systematization at the national level of the emergency through the development of the metadata by the MIUR with the AES program [52], then re-development by Legaambiente with annual reports and, in 2019, by Fondazione Agnelli [53]. This picture must guarantee temporal continuity and must be centrally managed by the state to allow coordinated control and the identification of specific management strategies.

According to the last analysis (MIUR 2019 data), the situation of school buildings at the national level is the following: Of the 40,151 functional school buildings in Italy, under the control of local authorities, 42\% were built before 1971, 30\% between 1971 and 1983, and 28\% from 1984 onwards. Only $53.2 \%$ of the buildings have the static test certificate (in Italy, the obligation of the static test certificate is sanctioned by law no. 1086 of 5 November 1971); $22.3 \%$ of the buildings without the static test certificate were built before 1970 . Nearly $60 \%$ of Italian schools do not have a fire prevention 
certificate; $53.8 \%$ do not have a certificate of usability/habitability; $43 \%$ are in zones 1 and 2 (high seismic risk), while the remaining are in seismic risk zones 3 and 4 .

It is difficult to imagine that all projects of restructuring and adaptation to the different regulations can be implemented in a short time, given the high number of Italian schools-around eight thousand-that have been declared inadequate.

However the strategies of reuse hypothesize a partial reconversion to other uses and a certain number of interventions capable of restoring to this vast heritage a dimension of adequacy for the needs of local communities, taking into account concepts based on the relationship between architecture and contemporary pedagogy, as evidenced by the vast scientific literature that addresses the issue [54-59]. On the other hand, Montessori and Freinet in Europe and Dewey [60-62] in the U.S.A., to name a few, had already stressed the essential role played by physical space for qualitative learning - the space where one learns influences learning; not all places are the same.

The new pedagogical paradigms, having ascertained the influence on the environments and students, focus on the students and their needs, imagining an open, inclusive school [63,64], a real house of knowledge. The school is no longer a place for teaching alone, but for the cultural development of an entire community, a civic reference, and a place of intellectual, social, and cultural exchange. This is an evolution of the functionalist vision already formulated in 1959 by Talcott Parsons, who considered a class as a social system [65].

Traditional schools, with their corridors scattered with classroom doors, can be interpreted through Foucaultian disciplinary technology, while new educational clusters seem to use Deleuze's social theory for connectivity and flow architecture. The shift from a teacher-centered model to a student-centered model reverses the spatial concept from clusters of closed classrooms to a more open spatial assemblage, a connective system of socio-spatial relations consisting of heterogeneous elements that are assembled into a whole that is not static, but dynamic and susceptible to infinite variations according to specific requirements or necessary conditions [66].

The procedure and standardized technical solutions that have become established in Italian school buildings since the 1960s provide an almost exclusively quantitative interpretation of the school based on functions and uses of specific materials, disregarding the relationship with the territory and the qualitative aspects of spaces, and leaving aside the principles identified by the new pedagogy.

The research we carried out in recent years on a selection of schools in the south of Italy analyzes a series of case studies through the cataloguing and categorization of school buildings and through a census of school complexes in the Crater regions aimed at the schematization of models to support the design of new strategies for their redevelopment. Architectural, technological, and construction elements belonging to specific historical periods of construction are identified and catalogued through the matrix to be the basis for spatial redefinition work that does not alter the buildings with respect to the peculiar features of the period they belong to if the features are identifiable.

In addition to the formal interpretation of the new teaching models, it is necessary to renew most of the structures through seismic adaptation, energy efficiency, and improving the quality of educational environments.

The importance of the participation of school managers and teachers in the definition of the project with the architect is clear, without, however, forgetting the direct contact with the students. A new type of interaction between the state, school institution, users, and designers was already desirable in the 1970s [67], but today, it seems even more necessary for the construction of new spaces in yesterday's buildings, metabolizing today's pedagogical models, but leaving open possibilities for future modifications, as in the recent projects of the Fermi (BDRbureau) and Pascoli (Archisbang) schools carried out following a competition of ideas promoted by Torino fa scuola, a project supported by the Compagnia di San Paolo and the Giovanni Agnelli Foundation in collaboration with the city of Torino and the Fondazione per la Scuola (2019) [68].

Models have been identified through well-defined strategies, which aim at renewing the school building scene and restoring the divide between cities, institutions, public buildings, and users. 
Schools today, enriched with new functions, are not only places dedicated to education, but environments that encourage the construction of "bridges" between generations and different cultures; they are spaces and opportunities for dialogue between public administration and citizens as well as learning environments, but also service centers for the territory, places for children, and points of reference for the groups of associations that operate and gravitate in urban realities.

The restructuring process is like a "reconstruction after a disastrous event" -in our case, earthquakes - and needs coordination capable of preventing individual isolated actions from governing the change, following contingent needs, so as to respond instead to the long-term needs of local communities [69] with concerted design scenarios based on solid analysis and parameters.

\section{Definition of the Formal Matrix}

The results of the survey carried out by Luccarelli, M. and Pannestrì, D. for the redevelopment of indoor and outdoor spaces through the study of the ratio between air and light [70] are an important starting point for the construction of analytical tables based on a diagnostic protocol-a technical-operational guidance tool aimed at controlling indoor air quality in school buildings, supporting the environmental and technological upgrading of existing buildings. This method, which mainly collects technical data, has been combined with a collection of data able to investigate the formal aspects linked to different historical periods that influenced the design of school infrastructures in order to define a survey matrix capable of identifying the specific characteristics of the temporally located buildings.

The definition of this matrix takes into account the regional distribution in the involved areas of the buildings belonging to the different periods of construction, and is a timeline of the main legislative references and the architectural analysis of a case study related to each period through volumetric axonometry, plan distribution, and spatial conformation of one of the educational spaces. The matrix aims to identify the various details that the different design periods have determined in the different architectures. The difficulty of distinguishing formal outcomes from different periods often leads to interpretative controversies that require a cognitive support capable of comprehensively reading a multi-faceted complexity.

The reference periods are illustrated below.

\subsection{Matrix 1: $1850-1920$}

School buildings built before the Second World War consist of buildings of historical interest, which cannot always be adapted to the regulations and spatial needs identified by the new pedagogical models.

In the period beginning before the unification of Italy, the school was a sort of protection for the territory by the state, which took care of its citizens through education. The buildings of the first-level primary and secondary school were those of municipal authority, and took the German model as a reference, with a linear arrangement of the classrooms facing a long corridor, wide enough to allow distribution and recreational activities. The state-run higher education institutions were distinguished, as Checchi states, by a mainly eclectic style [71]. The layout was linear, U-shaped, or L-shaped with courtyards; the exposure of the classrooms was to the south, and the numerous windows allowed plenty of light; the accesses were clear and easily visible thanks to long corridors, and the facade tended to be recognizable in relation to the context thanks to decorations and fine finishes. In accordance with the Coppino Law of 1877, the spaces were still subdivided according to sexes; the connections and service spaces called for large dimensions and light to favor distance and safety in the dispersion of flows [72].

Between 1901 and 1907, there was a 47\% increase in the number of students from 2.5 to 3.8 million; this increase required a considerable increase in new buildings. Architects such as Camillo Boito played a key role in the definition of the new school spaces of state authority [73] by drawing up 
specific directives for their design. For the construction of the matrix, we took into consideration the school he designed in Milan in Via Galvani, which was reproduced in a similar way in Padua.

\subsection{Matrix 2: 1921-1955}

Buildings prior to the first Italian anti-seismic law had significant spatial (functional, dimensional, formal, etc.) and structural problems.

The second period identified includes some exemplary cases, such as Sant'Elia by G. Terragni [74], with a detachment from canonical typologies and a revisitation of the relationship between space and education, inspired by the new contemporary educational methods, such as Steiner's active school and Montessori's method. However, these apparently innovative experiments, according to J. Kirkpatrick, were influenced by market policies and the quantitative vision of a school [75] as an affirmation of the presence of the state in the daily life of the population. In fact, during the period of the fascist regime, the school was seen as a key element in the construction of Italian society, considered as the holder of the values that the regime supported: unity, identity, teamwork, and physical activity as part of developing the spirit. These values will create projects with large spaces and an architectural composition of monumental proportions. The Gentile Reform in the Royal Decree 06/05/1923 [76] established the need to include suitable spaces for physical activity, large squares for events, and a monumental composition of the building that would stand out in the urban context thanks to the use of rationalist shapes, fine materials such as marble, and large windows.

In 1923, the Gentile Reform [76] estimated the deficit of suitable classrooms (many students at this time used to learn in apartments or even in rooms located in multifunctional buildings) at $40 \%$, with peaks of $80 \%$ in the South. Parameters were established for the adaptation of the school facilities: The number of classrooms had to range from 10 to 30 per building, the toilet facilities had to be adequate, as well as the air/light ratio; the buildings had to have at least one indoor gymnasium with changing rooms, possibly a swimming pool, a medical room, a library, administrative rooms, an educational museum, drawing, singing, technical education, and home economics laboratories.

In the post-war years in Italy, the typology par excellence was that of repetitive and modular elements in the face of a sudden demand for square meters: courtyards or L-shaped buildings, preferably on two floors, with a large or multifunctional classroom and full use of space to increase the number of classrooms as much as possible. It was in 1949 that the School Building and Outdoor Education Competition, announced by the Ministry of Public Education, was won by Ciro Cicconcelli, who was influenced by John Dewey's pedagogical ideas on active participation and the conformity of spaces to the level of total accessibility [77].

The case study taken into consideration for the second matrix is located in Ostia Lido, Corso Duca, and was designed by Ignazio Guidi, who shared his design ideas with engineer Nervi (auditorium in Rome in 1935), trying to create an interpretative model of school building to be spread throughout the Italian territory [78].

\subsection{Matrix 3: $1956-1975$}

In 1960, in number 245 of Casabella [79], Cicconcelli published reports of the research carried out between the post-war period and 1958; these saw the school building composed of several parts: classroom block, complementary classroom block, laboratory block, auditorium and gymnasium block, library and museum block, refectory block, and office block.

These ideas in Italy influenced the 1956 Presidential Decree for school buildings, where the European principles of a more open, constructively modular school were followed both through the involvement of teachers, pupils, and institutions and by opening up to the community [80]. Four books were published by the Study Center of School Construction for the design of the four educational spheres [81]. The drive of the economic boom of the 1960s and 1970s needed decisive action to overcome the lack of classrooms, with an estimated need for 1,700,000 student places, which, in 1964, was partially met with a five-year construction plan. Because of the economic boom and the relative increase in 
births, the Ministerial Decree of 21 March 1970 established certain design parameters on the minimum standard of space and the use of building materials. The classrooms had to accommodate a maximum number of 28 students with large inter-connecting areas so they could be used as recreational space. The materials to be used had to be standardized to reduce construction time, such as with reinforced concrete for the structures and brick for the infill panels. The minimum air/light ratio was set to 1/10, as was the span between the pillars of the structural scan of the buildings. The establishment of the unified middle school in 1961 and elementary schools in 1962, the prospect of having construction sites open throughout the peninsula, and Law 820/24 of September 1971 [82], which sanctioned a distribution throughout the territory of the buildings, meant that the building system used up to then, consisting of load-bearing masonry or reinforced concrete structures, had to be implemented with a prefabricated production so as to intervene quickly and be qualitatively controlled in all regions [71]. The school chosen to identify the design criteria of the period is in Chirignano, Venice and was designed by Gino Valle. The architect, together with Aldo Rossi and Luigi Pellegrini, sought a good-quality standard in repeatability and modularity as well as a new vision of the school space to be spread nationwide [83].

\subsection{Matrix 4: 1976-2000}

School buildings built after the entry into force of the first anti-seismic law and, specifically, after the earthquake in the 1980s were often prefabricated buildings whose obsolescence is linked to a short period of about 30 years.

The promulgation of the new Regulations of Ministerial Decree of 21.3.1970 [84], which was suspended and then revised in 1975 with the Ministerial Decree of 18 December 1975 [85], introduced some innovative ideas that defined the school building as a continuous education in a larger context. The concept of class was revised, now based on pupils' attitudes and the flexibility of spaces, large lights, floating floors, and equipped ceilings, with a distinction by cycle; the integration between the various environments from a spatial and functional point of view was fundamental. From the late 1970s and early 1980s, however, there was a decrease in population growth, with a consequent reduction in the construction of school buildings. In the Ministerial Decree of 1975 [85], with various amendments until 1977, regulations on fire safety, thermal insulation of buildings, and, in 1980, accessibility for the disabled were issued. The consequence was a tendency to include external staircases, fireproofing, and external insulation directly in the early stages of the design of new buildings and adaptation of the existing ones. There was a reduction in new buildings that adopted repetitive models in line with regulations: Straight buildings that connected with other volumes generated green spaces and interstitial zones. The distribution facilitated accessibility, the placement of energy efficiency devices, maintenance, and administrative management, but true integration between architecture and pedagogy was still a long way off.

The building taken as a reference for this period is in Tor Bella Monica, Rome, designed in 1985 by Francesco De Micheli in reinforced concrete and brick [86]. The need to comply with the 1975 standards implies a design that reflects the criteria of accessibility, safety, and energy efficiency. In 1980, De Micheli, together with the other designers N. Campanini, D. Ciaffi, F. W. Facilla, and R. Giuffrè, collaborated on the creation of the school complexes of Area Plan 167 in Rome [87].

\subsection{The New School}

As for the more recent school buildings, those from 2000 to date (a few new buildings were constructed due to the significant reduction of students), they have been considered as models rather than for the identification of a given matrix. Two schools were taken as models: the Fermi School in Turin, designed by BDRBureau, with a mention of "Restoration and recovery works" at the 2019 Festival of Architecture, and the Pascoli School in Turin, designed by Archisbang [43,88]. They, in fact, mostly follow the new directives of pedagogy, trying to implement the "constructive thinking activities" with the new functions and new criteria of spaces. The new didactic/educational model is metabolized in a design that considers all the components of the system: from the city to the neighborhood, from the 
building to the single furnishing element, as a single whole. The benefits of this paradigm change can be seen at both the urban and the building scale, with important repercussions on the identity sphere of local communities [55]. This kind of spatial setting makes the school identify itself as a real Civic Center with great freedom in the setting of plans and increased value of connecting spaces, which assume a meaning for themselves equal to that of real educational spaces.

\subsection{Methodological Synthesis of the Matrix}

Research in the U.S. by Nair, P., Fielding, R., and Lackney, J., which identified as many as 29 patterns for the project of new school buildings, was taken as a reference for its vast organization and detail in the individual elements that were identified to achieve the design of a healthy and functional learning environment [58]. Starting from the American research, we tried to determine for each individual building a degree of belonging to System, Connective Tissue, and Element, as well as their relative scales. The qualitative characteristics of the elements are related to the temporal categories by identifying formal and technical characteristics of the individual buildings (Figure 1) through the following three factors:

System-definition at the urban morphology level of the building and distribution, consisting of: Environmental performance, which includes the qualities with an impact on the context.

Accessibility, which includes the characteristics that implement the contact with the community and the use of the building.

Connective Tissue-identification of connective spaces and interactions at a pedagogical level, consisting of:

Part of the whole, which is the identification of connective spaces that contemplate a specific function and their interactions.

Spatial quality, which is the identification of those characters that encourage interactions between participants.

Element-definition of the aspects that characterize the individual spaces of the design, consisting of:

Expansion of activity, which includes all elements that help the user to use and discover the space, triggering activities of reasoning or discovery.

Spatial performance, which identifies the elements that interact with the user and that contribute to defining a safe, healthy, and pleasant environment [58].

In System category, the enclosure of a school or the greenery that surrounds it, as well as the access axes and direct connections with the city, is intended as an example; elements that make it possible to connect various parts of the building both physically and visually, such as corridors and external passageways, are included in Connective Tissue; Element concerns devices inside the school that increase students' performance, such as natural and mechanical ventilation elements or spaces and areas that are diversified in their functions thanks to the placement of specific furnishings. This operating mode allows an a priori categorization in the analytical phase, which is useful for identifying subsequent specific design strategies, which already appear clear in their scale of intervention in relation to the spheres on which they can produce a meliorative impact. 


\begin{tabular}{|c|c|c|c|c|}
\hline & $1850-1920$ & 1921 - 1955 & 1956 - 1975 & $1976-2000$ \\
\hline $\begin{array}{l}\text { Enviromental } \\
\text { Performance }\end{array}$ & $\begin{array}{l}\text { protection boundary } \\
\text { facade identity } \\
\text { linear solar exposition }\end{array}$ & $\begin{array}{c}\text { defined block } \\
\text { monumental composition } \\
\text { diagonal Exposition }\end{array}$ & $\begin{array}{l}\text { open boundanies } \\
\text { block composition }\end{array}$ & $\begin{array}{l}\text { organic block } \\
\text { mezzanine }\end{array}$ \\
\hline Accessibility & $\begin{array}{l}\text { axes accessibitity } \\
\text { Inear distribution }\end{array}$ & $\begin{array}{c}\text { different accesses } \\
\text { broken line distribution }\end{array}$ & $\begin{array}{l}\text { extemal paths } \\
\text { single access } \\
\text { modular distribution }\end{array}$ & $\begin{array}{l}\text { public access } \\
\text { multiple axes } \\
\text { connected volumes }\end{array}$ \\
\hline $\begin{array}{l}\text { Part of the } \\
\text { whole }\end{array}$ & $\begin{array}{l}\text { class as a center } \\
\text { gathering classroom }\end{array}$ & $\begin{array}{c}\text { specific class } \\
\text { volumes intersection } \\
\text { common areas }\end{array}$ & $\begin{array}{l}\text { modular class } \\
\text { educational connections } \\
\text { extemal pavilons }\end{array}$ & $\begin{array}{l}\text { plug-in classroom } \\
\text { block pavilons } \\
\text { plug-in services }\end{array}$ \\
\hline $\begin{array}{l}\text { Spatial } \\
\text { Quality }\end{array}$ & $\begin{array}{l}\text { wide connections } \\
\text { pavilon on the edges }\end{array}$ & $\begin{array}{l}\text { wide windows } \\
\text { indirect relation }\end{array}$ & $\begin{array}{l}\text { continuos windows } \\
\text { double heigh }\end{array}$ & $\begin{array}{l}\text { escape space } \\
\text { direct relation }\end{array}$ \\
\hline $\begin{array}{l}\text { Expansion } \\
\text { of activity }\end{array}$ & $\begin{array}{l}\text { Inear prospective } \\
\text { trasparent connections }\end{array}$ & $\begin{array}{l}\text { multiple prospectives } \\
\text { double heigh foyer }\end{array}$ & $\begin{array}{l}\text { central nave } \\
\text { external covers }\end{array}$ & $\begin{array}{l}\text { internal view } \\
\text { double facade }\end{array}$ \\
\hline $\begin{array}{c}\text { Spatial } \\
\text { Performance }\end{array}$ & $\begin{array}{l}\text { filter zone } \\
\text { fixed formiture } \\
\text { natural devices }\end{array}$ & $\begin{array}{l}\text { functional partitions } \\
\text { mechanical devices }\end{array}$ & $\begin{array}{l}\text { exchangable fornitures } \\
\text { technological devices }\end{array}$ & $\begin{array}{l}\text { point of light } \\
\text { visual connections }\end{array}$ \\
\hline
\end{tabular}

Figure 1. This table depicts the formal matrix identified by the analysis of the construction periods that characterized Italian school buildings, divided through the spatial characteristics identified by P. Nair and R. Fielding [58]. Developed by the authors.

\section{Survey Methodology}

Once the formal matrix was defined, the school buildings affected by the earthquakes between August 2016 and January 2017 were analyzed. The aim was to detect the buildings in use or partially affected by the earthquake in the territory and categorize the actions to be implemented for a systemic recovery of school environments through an architectural-pedagogical vision that goes beyond the purely quantitative references. In fact, due to the economic boom and the increase in births, the construction of new school buildings in Italy in the 1970s followed the provisions of the Ministerial Decree of 18 December 1975 [85] regarding the use of standardized materials and construction methods at the expense of a reduced introduction of qualitative parameters linked to pedagogical innovation, such as the reevaluation of the Connective Tissues, such as the corridor, which has gradually become a real educational environment.

\subsection{Survey}

Based on a census that catalogued brick buildings in the crater regions in 2018 [89], usable school buildings from the MIUR AES database [52] were censused to investigate formal aspects in relation to distribution and technological characteristics. Another analysis and comparison tool took the Ecosystem Report of Legambiente scuola as a reference, allowing us to have a clear vision at the national level of the school building heritage and its state of conservation so as to be able to compare data on a national scale with regional data [50]. For this purpose, 30 school buildings were analyzed in 25 of the municipalities included by the Italian Parliament in the Law Decree of 17 October 2016, no. 189 and in the Law Decree of 9 February 2017, no. 8 [90] in the crater territory between Abruzzo, Lazio, and Umbria [91], excluding the municipalities of Marche due to the huge number of buildings affected, which exceeded that of the other three regions put together.

The buildings considered were the primary and lower secondary schools currently in use and those of the municipal authority, from which it was possible to identify personal, quantitative, and qualitative data in the National Registry System, AES, and in the indications of the Scuola In Chiaro catalogue of the 
Ministry of Education [92]. The data collection began at the end of June 2019 and lasted about a month, leading to the cataloguing of 30 buildings with a relative photographic report. Therefore, data were collected on each building, then compared with the Scuola In Chiaro system of the Ministry of Education [92].

Through the application of the formal matrix, the distinctive environments of the structures in need of intervention were identified to bring them back to a state of safety compatible with future implementations and redevelopments. In fact, the prospect of a quantitative redevelopment, which is required to make the buildings safe, implies a redevelopment of the spaces capable of improving the quality of use.

The survey methodology is, therefore, divided into the collection of information as follows:

Data-year of construction/number of students/total surface area/built area/state of the work/type of construction.

Papers-context plan/building volume.

Formal matrix-representation of the data in a diagram that will later enable categorization. The formal matrix, derived from the analysis of historical periods, is the tool used to define the characteristics of school structures and to outline the aspects that distinguish them in the relationship between architecture and educational methodology (Figure 2).

Technical and formal evaluation-notes resulting from the comments of the managers, municipal technicians, and people involved in the school institutions combined with technical evaluations.

Photographic report-photographs were taken during the survey to show elements, materials, critical points, or characteristics of the buildings.

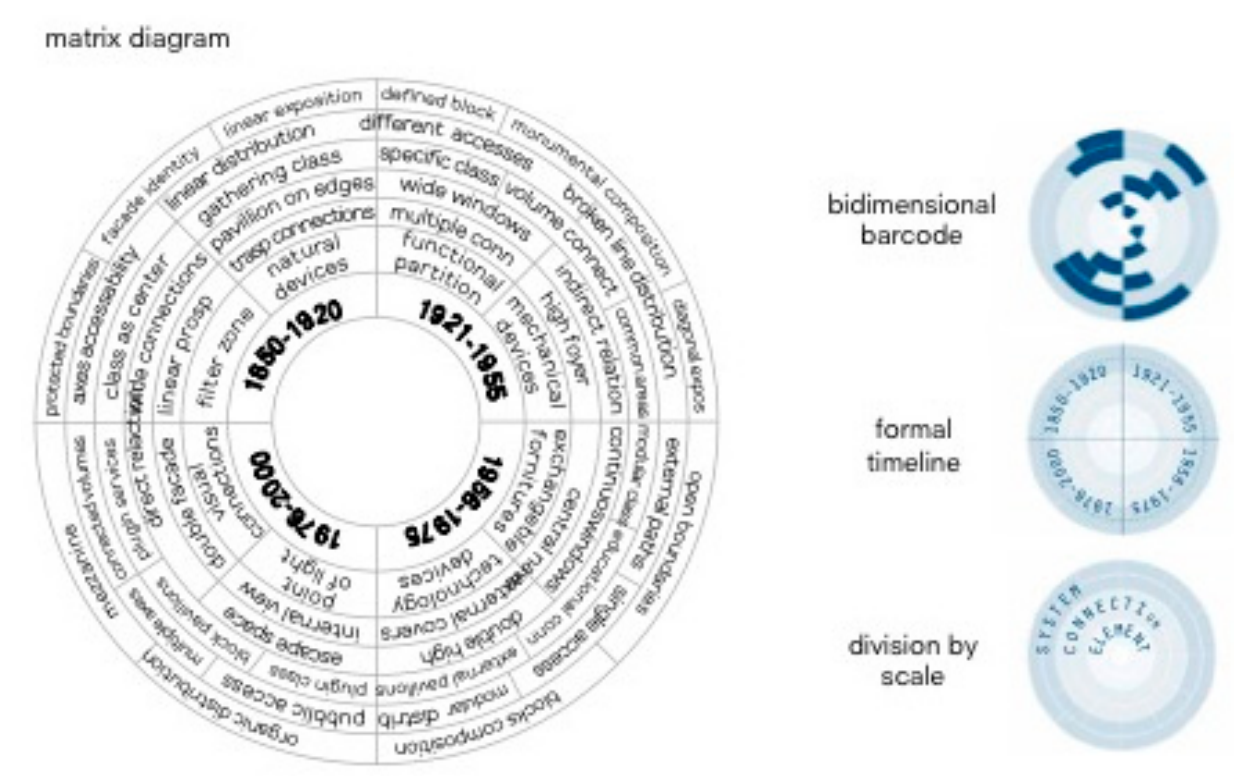

Figure 2. Above is a hypothesized configuration of the table in Figure 1, similar to the two-dimensional barcode that is being studied, in order to digitally store information regarding the specific characteristics of the buildings identified. The details of the period are entered into a system and used as parts of a code that will help identify the action categories. Developed by the authors.

\subsection{List of Functions and Spatial Characteristics}

During the analysis, the functions and distribution of the buildings were considered to interpret the shortcomings and to direct the redevelopment works of the project towards a reuse of the structures [31]. The aim was to identify these shortcomings with respect to the educational standards analyzed so far so that specific work could be carried out on selected groups of buildings through categorization. The ratios between buildings, the relationship with the enclosure, and the layout distribution were identified (Figure 3). 
During the survey, several technical characteristics were also highlighted regarding the possibility of future interventions [31]. Therefore, analytical categories were identified to facilitate the subdivision of the redevelopment actions: distribution of openings, prevailing construction technology, and quality of the architectural work.

\begin{tabular}{|c|c|c|}
\hline " single & 플 grid & $\equiv$ continuos \\
\hline If $\mathrm{C} / \mathrm{A}$ & \# prefab & I I masonry \\
\hline IfII Very good & 珮 good & 缌 bad \\
\hline . & (8) Gym & Il canteen \\
\hline$\square$ library & (2) Lab & AिAि class \\
\hline 쏬소 Gathering point & (A) Playground & al garden \\
\hline I"I sistem & $=$ axe & E center \\
\hline$=$ front & - offset & = beside \\
\hline 眀 linear & 㻤 broken & 眀 central \\
\hline
\end{tabular}

Figure 3. Representative diagrams of the qualitative characteristics of buildings from top to bottom: functional, distributive, technological, propaedeutic, and categorization. Developed by the authors.

\subsection{Categorization}

In order to try to intervene with common strategies for a good part of the school buildings, it is necessary to divide them into categories according to their architectural, formal, and technical characteristics. Taking the classification for interventions proposed in another research work for the cataloguing of formal outcomes of architectural projects as a qualitative tool as a reference [31], three categories have been identified, resulting from the interactions between the data described above and their formal characteristics identified by the formal matrix based on periods and functional and volumetric diagrams. Thus, specificities have been associated in the location in the territory, in the number of buildings, and in their internal distribution. Several types of school buildings have been identified through the matrices and data collected by the Ministry of Education (AES) [52] to strategically intervene in the redevelopment of the educational spaces.

Below are the three categories identified by cross-checking the previously analyzed data and their spatial characteristics derived from the formal matrix and diagrams.

\subsubsection{Systemic Category}

The school complexes that distribute their functions over a number of buildings (starting from three) have been grouped in the first category. In this typology, the buildings take on different roles with respect to the city and the community due to the impact in terms of volume and the various school and external users of the spaces; moreover, the external connective tissue becomes an essential part of the school design as a space that intercepts the urban fabric. Generally formed by several buildings, these school complexes overlook well-marked road axes with a straight layout that follows the solar orientation and generates large inner courtyards (Figure 4).

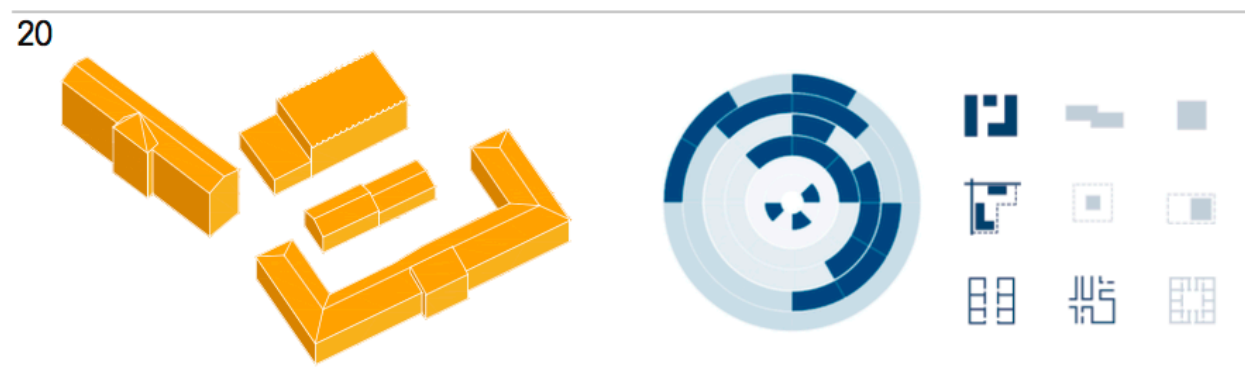

Figure 4. Definition of the Systemic category identified during analysis. Developed by the authors. 


\subsubsection{Connective Category}

School buildings generated by a sum of volumes have been included in the second category; they generally have at least two floors above ground and distribute their internal functions on linear axes, e.g., long, generally dark corridors, as they are located in the center of the building wing and exclusively distributive. The typology can have volumes with different heights and a well-defined functional division, which translates into structures of different shapes and types connected by walkways or internal passageways. The distribution layout is straight with exchange nodes in the intersection of the volumes (Figure 5).

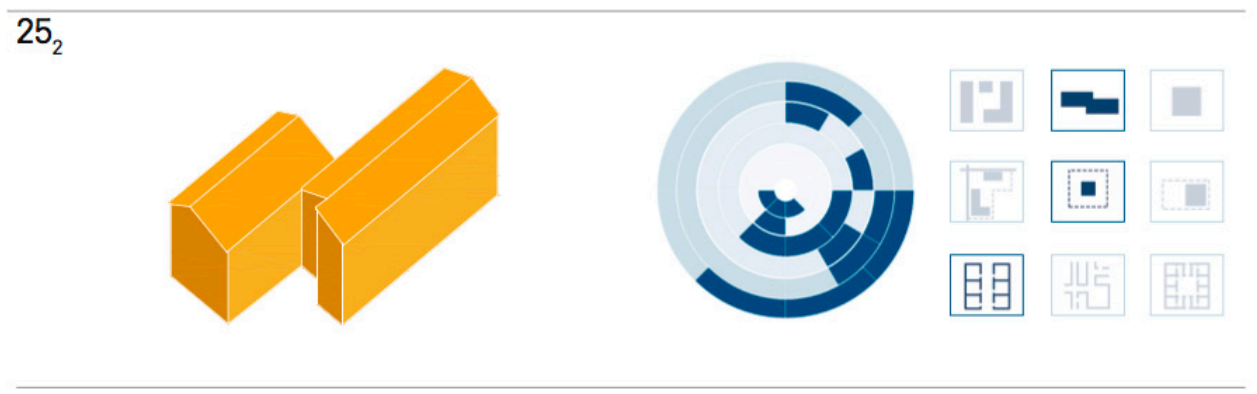

Figure 5. Definition of the Connective category identified during analysis. Developed by the authors.

\subsubsection{Introverted Category}

In the third category, the school complexes formed by a single building have been taken into consideration, which often lack the basic functions identified by today's pedagogy, such as a gymnasium, auditorium, or informal meeting point. The distribution takes place around a central control point that manages the flows and connects the functions of the various levels. All common activities and recreational activities take place around this core, but are affected by the lack of light. The buildings are inscribed in a well-defined enclosure that is detached from the school building or is adjacent on one side to generate internal courtyards and/or perimeter voids between the volume and the enclosure (Figure 6).

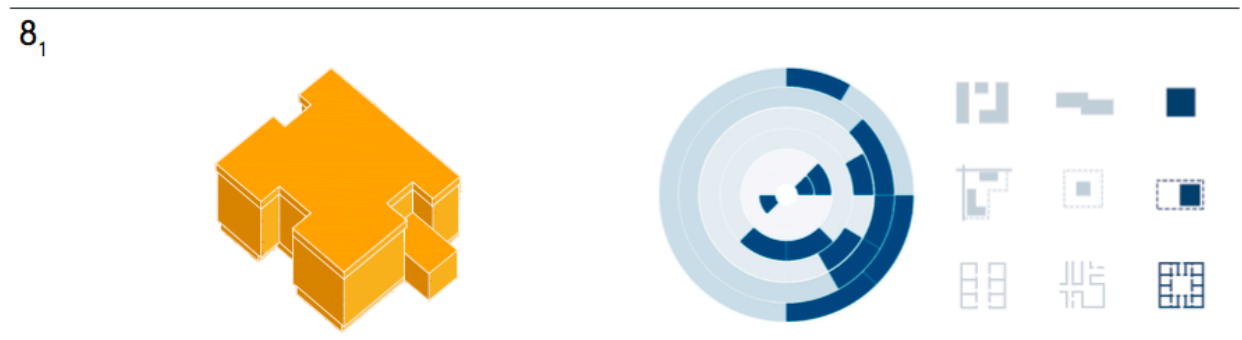

Figure 6. Definition of the Introverted category identified during analysis. Developed by the authors.

\section{Adaptive Design Strategies}

After the census, the analysis, and the cataloguing of the selected schools, three possible intervention strategies that can be associated with the suggested categorizations were proposed: systemic, connective, and introverted, each of which is expressed at the urban, architectural, and flow level.

\subsection{Systemic Strategy}

This strategy aims to solve the problems of connecting the school structures, consisting of several buildings, with the city, in order to generate, according to the development idea of the school/Civic Center, new functions, such as theatres, areas for associations, or sports facilities, which are receptive to the community. 
To regenerate school spaces in line with the Civic Center concept, it is essential to act on the container, but also on the spatial relations it generates through architectural strategies capable of creating connections with the social context. The distribution of the functions, accessibility, and flow system are key elements of the management strategy of the structure and its conversion into a cultural center. The project must relate the flows with the functional distribution using different patterns and roofing systems to connect all the buildings of the system and expand the space, establishing internal-external continuity.

In the approach to the redevelopment of the school volume, it is necessary to keep in mind the formal characteristics towards which it is aimed: Common Identity-formal coherence among all components of the building, changing the compositional concept of the individual building to that of the entire system; Facade Open to the City-establishing a continuous relationship with the community through the formal definition of the facades; Safe Space-the school enclosure must be clearly identifiable and secure so as to grant the highest degree of freedom of the system; Direct View-generating direct visual connections at the accesses with the main axes so as to support the fluidity of the system; Cluster-the division of volumes to distribute the workforce functions and to facilitate flows and opening hours; Connection with the Greenery-the design of the outdoor spaces must allow an internal/external visual connection as well as with the surrounding space, with a system flexibility that can be modified according to needs.

The definition of the volumes takes place by grouping the functions, which are distributed according to the different types of use, but unified in a single system.

The school/Civic Center is made up of elements grouped in clusters:

- Canteen;

- Library/Auditorium;

- Laboratories/Classrooms;

- Gym;

- Administration/Associations.

The architecture/pedagogy binomial acts on the reform of clusters and the spaces within them in the face of an opening towards the external connective tissue. The internal/external connection belongs to all the spaces of the clusters, generating continuity and interrelation between the individual parts, as well as a secure condition (Figure 7).
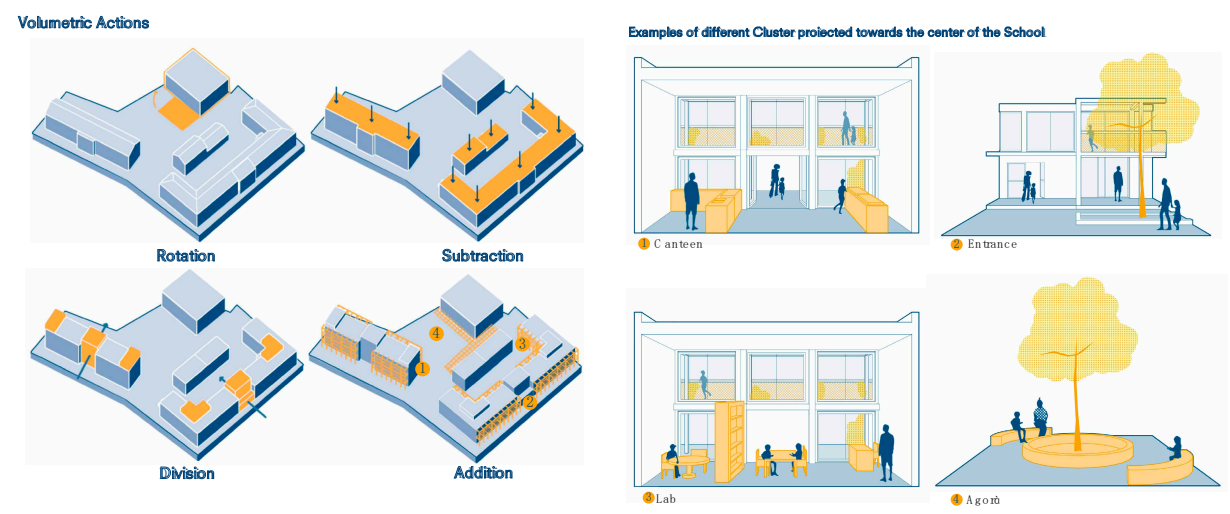

Figure 7. Volumetric actions' and clusters' qualitative scenarios—systemic strategy. Developed by the authors.

\subsection{Connective Strategy}

The connective strategy aims to expand the fifth educational space, defined by the Manifesto INDIRE on Learning space [93] as the space of connection, expressing it in the new functions proposed by contemporary pedagogy. In the approach to the redevelopment of the school building, it is necessary 
to keep in mind the formal characteristics at which it aims: Diversification of the accesses-management and division of the flows according to their degree of entropy, dividing the accesses for the users who relate with the city from those of the more private logistics and maintenance; Expansion of the fabric - expansion of the connective spaces through the addition of volumes for the missing functions so as to expand the internal distribution patterns and differentiate them according to uses; Volumetric variation-volumetric organization through the use of filter elements and thresholds, such as terraces or external connective spaces, increasing the usable surface area and projecting the functions towards the outside; Functional Envelope-inclusion of facade systems for energy efficiency of south-facing facades, capable of forming new connective tissue between classrooms and interstitial spaces.

The strategies of volumetric increase, in line with the new pedagogical needs, determine an expansion of the spaces that, together with the contraction of the school population density, allow the reevaluation of the distribution system. The "corridor" becomes part of the educational fabric of the school and, as stated in the Manifesto INDIRE on Learning space [93], the distributive space can be redefined as interstitial space or informal space, which, with a variation of the configurations, can generate different educational realities:

Locker: Space for changing clothes and storing personal materials.

Lair: Interstitial space dedicated to individual or small-group activities.

Loggia: Place of intersection between external and internal connections that is able to accommodate large or small groups.

Terraces: Connective and educational places that intersect with the protrusions that are dedicated to external connections.

Connective reevaluation strategies review connecting elements, such as staircases or steps, that play a key role in managing flows and safely carrying out activities.

These have been divided into:

Internal Connections: The internal connections are placed in strategic and clearly identifiable points in the system; they are incorporated in the connective tissue to regenerate the space and to allow their use as permanent furniture.

External Connections: The external connections act as a systemic binder for the functions-those that are exclusively educational and those that are more specific to the Civic Center. The accessibility system must follow the different flows, differentiating itself in patterns.

Facade Connections: Direct connection with the public space and with the structures located on the ground floor that enlarges the space of the horizontal connections, making it useful for flows during classroom changes and intervals (Figure 8).
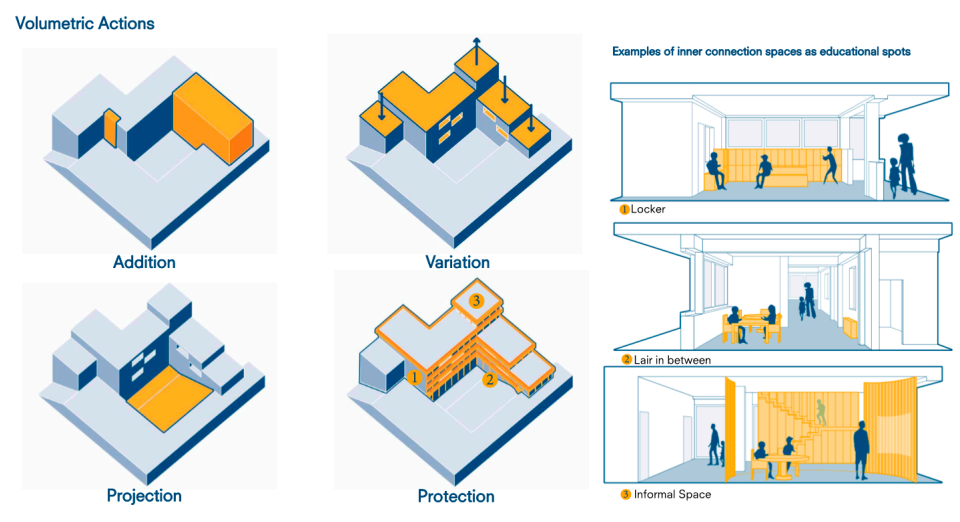

Figure 8. Volumetric actions' and clusters' qualitative scenarios-connective strategy. Developed by the authors.

\subsection{Introverted Strategy}

The introverted strategy aims at the redevelopment of buildings that expand inwards, inscribed in a narrow enclosure that limits the common areas to the central distribution areas of the building. 
The extension of the internal space can be implemented by adding patios or by appropriating external spaces, reusing urban voids to expand functions, and/or adding new ones.

In the approach to redeveloping the school building, the formal characteristics to be targeted must be taken into account: Development of Voids-the development of voids inside and outside the lot to increase the permeable surface of the structure; Expansion of the Fabric-acquisition of adjacent municipal areas to expand existing functions and add new ones; Identity of the Landmark-building a relationship with the external space and the community, thus strengthening the identity of the neighborhood and the school structure itself; Visual Connection-strengthening the visual connection of spaces to facilitate the use and control of different functions, especially in the connective tissue.

The strategies of volumetric increase aim to expand the functions within the school volume through the voids inserted into the system. The internal subtractions (which are possible if they do not jeopardize the stability of the building; they have to be verified by structure experts) allow the creation of a central void, which creates a visual connection with the whole floor and brings light to all the functions.

The distribution strategy must foresee a differentiation of the horizontal and vertical distribution, ensuring a safe and orderly flow management that complies with the transformation into a Civic Center.

The spaces generated by the development of voids are identifiable as:

Patio: Located in the center of the volume, it brings light into the building-into classrooms and laboratories. It is possible to create workstations for individual study or small groups with the help of furnishings, while outdoor activities can be carried out on the ground floor.

Loggia: Placed between the classrooms and the vertical connections, it guarantees the right amount of light and the possibility of extending the educational activities outside, thus maintaining safety, a certain protection, and renewed visual connections with the external greenery.

External laboratory: Located in the ground or basement floors, it generates a safe green space that allows teaching to expand outdoors, providing new educational spaces. The outdoor green spaces are connected in a flowing system to allow circulation at different times of the day.

Connected classroom: The educational space par excellence must be transformable, even with the help of mobile furniture, and visually connected with the other educational spaces and the central patio.

Portico: It connects to the building and the central void while maintaining a visual connection that allows different adjacent functions to be controlled.

Glazed corridor: Connection with visual transparency, which connects to the portico system that overlooks the external void so the activities that take place outside can be viewed and vice versa, safely creating different levels of entropy (Figure 9).
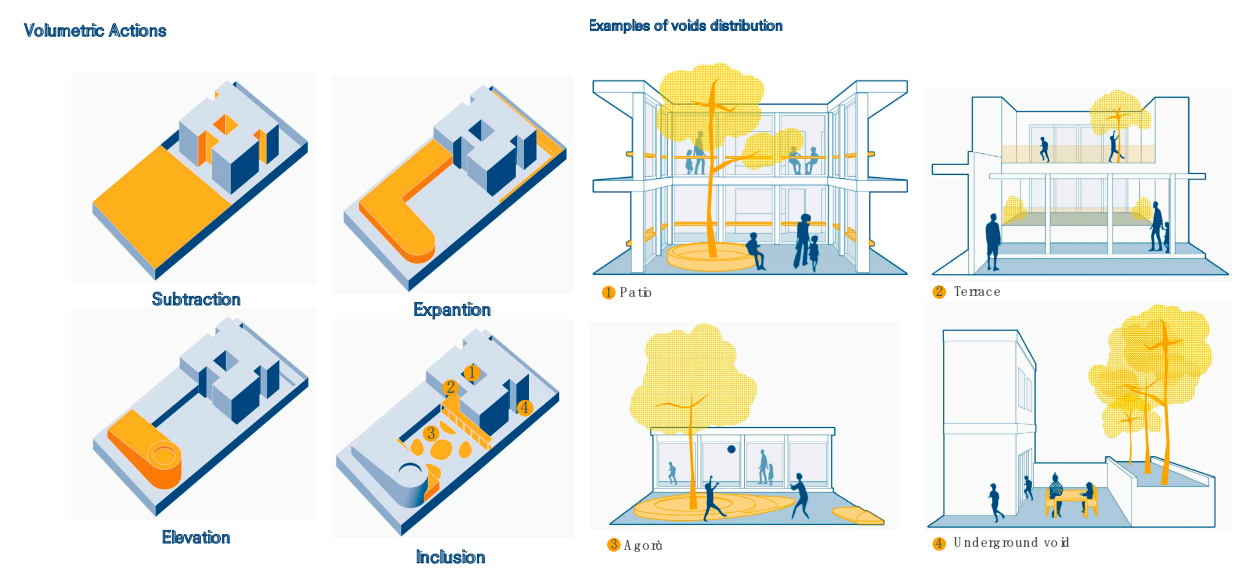

Figure 9. Volumetric actions' and clusters' qualitative scenarios-introverted strategy. Developed by the authors. 


\section{First Conclusions and Future Research Developments}

The methodological sequence model hypothesized by Andrew Charleson [94] for the preliminary architectural design, which proposes an interrelation between architectural and structural conception in a preliminary phase that is positioned between planning, programming, and the architectural project itself, highlights the need to identify timing for the coordination of design and for the interpretation of requirements to comply with seismic regulations as a structuring component in the definition of the design process. The formal results must be the result of these synergies, and the architectural project becomes the guarantor for the application and metabolization of the different technical requirements, as it is an integral part of the construction of a knowledgeable project to guarantee quality that integrates safety, sustainability, and resilience. The architect can explore the opportunities and constraints of earthquake-resistant structures exactly like those of pedagogy, sociology, planning, ecology, technology, and many others, thus analyzing and interpreting the same constraints as opportunities to make specific choices.

The cognitive matrices experimented upon in the research and now, in further study, can be used for the informatization of data by barcoding, and can be subject to modifications and further applications with consequent methodological improvements capable of leading to increasingly in-depth cognitive surveys that can offer public administrations and designers the largest possible number of determinants on the basis of which to plan the transformation of the current ones.

Knowledge and systematization of the relative data is necessary, with specific indications of the technical, quantitative, formal, and, above all, qualitative elements that characterize the transformation and design into a perspective of sustainable adaptation and reuse, but also of replacement or new sustainable construction that is compatible with the urban fabric, if required.

Author Contributions: Conceptualization, R.I.; methodology, R.I. and L.P.; survey and data collection, L.P.; 1. Introduction, 2. Architecture and Urban Design as a Tool for Transformation, 3. Materials and Methods, 7. First Conclusions and Future Research Developments and review of all of the paper, R.I.; the other paragraphs have been written by both the authors: R.I. and L.P. All authors have read and agreed to the published version of the manuscript.

Funding: This research received no external funding.

Conflicts of Interest: The authors declare no conflict of interest.

\section{References}

1. INDIRE. The Avanguardie Educative Manifesto. Available online: http://pheegaro.indire.it/uploads/ attachments/1946.pdf (accessed on 5 August 2020).

2. Alexander, C. The Timeless Way of Building; Oxford University Press: New York, NY, USA, 1979.

3. Pollo, R. Why architecture quality? In RE-Waterfront. A Sustainable Architectural Approach; Dahl, P.J., Pollo, R., Thiebat, F., Micono, C., Zanzottera, F., Eds.; Franco Angeli: Milano, Italy, 2019.

4. U.S.R.C. Ufficio Speciale Per la Ricostruzione dei Comuni del Cratere. Available online: http://www.usrc.it/ home/chi-siamo (accessed on 28 June 2020).

5. $\quad$ Elmqvist, T.; Bai, X.; Frantzeskaki, N.; Griffith, C.; Maddox, D.; McPhearson, T.; Parnel, S.; Romero-Lankao, P.; Simon, D.; Watkins, M. (Eds.) Urban Planet-Knowledge towards Sustainable Cities; Cambridge University Press: Cambridge, UK, 2018; pp. 462-482. [CrossRef]

6. Elmqvist, T.; Andersson, E.; Frantzeskaki, N.; McPhearson, T.; Olsson, P.; Gaffney, O.; Takeuchi, K.; Folke, C. Sustainability and Resilience for Transformation in the Urban Century. Nat. Sustain. 2019, 2, $267-273$. [CrossRef]

7. Pearson, L.J.; Newton, P.W.; Roberts, P. (Eds.) Resilient Sustainable Cities-A Future; Routledge: New York, NY, USA, 2014.

8. Tankard, C. How secure is your building? Netw. Secur. 2015, 2015, 5-8. [CrossRef]

9. Castaldo, P.; Ferrentino, T. Seismic Reliability-Based Design Approach for Base-Isolated Systems in Different Sites. Sustainability 2020, 12, 2400. [CrossRef] 
10. Palazzo, B.; Castaldo, P.; Vecchia, P.D. Seismic reliability analysis of base-isolated structures with friction pendulum system. In Proceedings of the 2014 IEEE Workshop on Environmental, Energy and Structural Monitoring Systems, Napoli, Italy, 17-18 September 2014; pp. 1-6. [CrossRef]

11. Long, J. Constructing the narrative of the sustainability fix: Sustainability, social justice and representation in Austin, TX. Urban Stud. 2016, 53, 149-172. [CrossRef]

12. What Is Horizon 2020? Available online: https://ec.europa.eu/programmes/horizon2020/en/whathorizon-2020 (accessed on 7 June 2020).

13. Kilicay-Ergin, N.; Colin, J.; Neill, C.J.; Sangwan, R.S. Integrating object-process methodology with attribute driven design. In Proceedings of the Annual IEEE Systems Conference (SysCon), Orlando, FL, USA, 18-21 April 2016; pp. 1-8.

14. Boholm, M. The semantic field of risk. Saf. Sci. 2017, 92, 205-216. [CrossRef]

15. Boholm, M.; Möller, N.; Hansson, S.O. The Concepts of Risk, Safety, and Security: Applications in Everyday Language. Risk Anal. 2016, 36, 320-338. [CrossRef]

16. Bubnovskaia, O.V.; Leonidova, V.V.; Lysova, A.V. Security or Safety: Quantitative and Comparative Analysis of Usage in Research Works Published in 2004-2019. Behav. Sci. 2019, 9, 146. [CrossRef]

17. Enciclopedia Treccani. Available online: http://www.treccani.it/vocabolario/ricerca/progettare/ (accessed on 3 June 2020).

18. Cuff, D. Architecture: The Story of Practice; The MIT Press: Cambridge, MA, USA, 1992.

19. Yaneva, A. Made by the Office for Metropolitan Architecture: An Ethnography of Design; 010 Publishers: Rotterdam, The Netherlands, 2009.

20. Yaneva, A. The Making of a Building: A Pragmatist Approach to Architecture; Peter Lang AG: Oxford, UK, 2009.

21. Cayer, A. From Archive to Office: The Role of History in Theories of Architecture Practice. Ardeth 2018, 2, 35-51. [CrossRef]

22. Pollio, M.V. De Architectura. The Architecture of Marcus Vitruvius Pollio; Gwilt, J., Translator; Lockwood \&CO: London, UK, 1874; Available online: https://warburg.sas.ac.uk/pdf/kfh125b2128022.pdf (accessed on 7 May 2020).

23. Alberti, L.B. De Re Aedificatoria. Available online: http://www.antichefornaci.it/blog/biblioteca/leon-battistaalberti-de-re-aedificatoria-tradotto-da-cosimo-bartoli-1784/ (accessed on 7 May 2020).

24. Plowright, P.D. Revealing Architectural Design: Methods, Frameworks and Tools; Routledge: London, UK, 2014; pp. 14-17.

25. Bocchi, R.; Marini, S. Re-Cycle Italy. In search of new life-cycles for the territories of waste and abandonment. Techne J. Technol. Archit. Environ. 2015, 10, 16-18.

26. Van Eyck, A. Beyond Visibility, about Place and Occasion, the in between Realm, Labyrinthian Clarity. In For Us; 1962; pp. 20-23. Available online: http://www.artefacts.co.za/main/Buildings/articles.php?artid= 1863 (accessed on 10 October 2020).

27. Hertzberger, H. Space and the Architect; 010 Publishers: Rotterdam, The Netherlands, 2000.

28. Smithson, A. (Ed.) Team 10 Primer; Studio Vista \& Reinhold: New York, NY, USA, 1968.

29. Sennett, R. The Open City. Housing and Urban Neighbourhoods; Urban Age; Newspaper Essay Berlin: Berlin, Germany, 2006. Available online: https://esteticartografias07.files.wordpress.com/2008/07/berlin richard_sennett_2006-the_open_city1.pdf (accessed on 12 July 2020).

30. Deleuze, G.; Guattari, F. A Thousand Plateaus; University of Minnesota Press: Minneapolis, MN, USA, 1987.

31. Ingaramo, R. Rust Remix; LetteraVentidue: Syracuse, Italy, 2017.

32. Baima, L.; Robiglio, M. Intensity of Uses and Spatial Devices. In Abandoned Buildings in Contemporary Cities: Smart Conditions for Actions; Lami, I.M., Ed.; Springer: Cham, Germany, 2020. [CrossRef]

33. Venturi, R.; Brown, D.S.; Izenour, S. Learning from Las Vegas, 1st ed.; The MIT Press: Cambridge, MA, USA, 1977.

34. Wilkinson, S. The Context for Building Resilience through Sustainable Change of Use Adaptation: Building Urban Resilience through Change of Use; Wiley: Melbourne, Australia, 2018; pp. 1-20.

35. Robiglio, M. RE-USA. 20 American Stories of Adaptive Reuse; Jovis: Barcelona, Spain, 2017.

36. Bullen, P.A. Adaptive reuse and sustainability of commercial buildings. Facilities 2007, 25, 20-31. [CrossRef]

37. Douglas, J. Building Adaptation; Routledge: New York, NY, USA, 2006.

38. Langston, C.A. The sustainability implications of building adaptive reuse. In Proceedings of the International Research Symposium on Advancement of Construction Management and Real Estate (CRIOCM 2008), Beijing, China, 31 October-3 November 2008; pp. 1-12. 
39. Ball, R. Re-use potential and vacant industrial premises: Revisiting the regeneration issue. Stoke Trent. J. Prop. Res. 2002, 19, 93-110. [CrossRef]

40. Science Communication Unit. Science for Environment Policy. No Net Land Take by 2050? Future Brief 14. 2016. Available online: http://ec.europa.eu/science-environment-policy (accessed on 20 June 2020).

41. Mohamed, R.; Boyle, R.; Yilun, A.Y.; Tangari, J. Adaptive reuse: A review and analysis of its relationship to the 3 Es of sustainability. Facilities 2017, 35, 138-154. [CrossRef]

42. Kurul, E. A Qualitative Approach to Exploring Adaptive Re-use processes. Facilities 2007, 25, 554-570. [CrossRef]

43. Grillo, F. Una Scuola Ristrutturata a Torino, Circondata da Pergolati Sospesi. Domusweb, 25 September 2019. Available online: https:/www.domusweb.it/it/architettura/gallery/2019/09/25/una-scuola-ristrutturata-atorino-circondata-da-pergolati-sospesi.html (accessed on 27 July 2020).

44. Fabian, L.; Giannotti, E.; Viganò, P. (Eds.) Recycling City, Lyfecycles, Embodied Energy, Inclusion; Giavedoni: Pordenone, Italy, 2012.

45. Bocchi, R.; Ippolito, F. Riciclare la città. IBC XXI 2013, 2, 1-5.

46. Fabian, L.; Munarin, S. (Eds.) Re-CycleItaly. Atlante; LetteraVentidue: Syracuse, Italy, 2017.

47. ESFA. Condition Data Collection, Guide for Schools, 2017. Available online: https://assets.publishing.service. gov.uk/government/uploads/system/uploads/attachment_data/file/652226/Condition_Data_Collection_ _CDC_Guide_for_Schools.pdf (accessed on 25 July 2020).

48. Perraudin, F. Revealed: One in six schools in England require urgent repairs. Guardian, $2019,8$. Available online: https:/www.theguardian.com/education/2019/dec/08/revealed-one-in-five-school-buildingsin-england-require-urgent-repairs (accessed on 5 June 2020).

49. Iovino, R.; Fascia, F.; Lignola, G. (Eds.) Edilizia Scolastica: Riqualificazione Funzionale Ed Energetica, Messa In Sicurezza, Adeguamento Antisismico; Dario Flaccovio Editore: Palermo, Italy, 2014.

50. Legambiente. Ecosistema Scuola-XIX Rapporto di Legambiente Sulla Qualità Dell'edilizia Scolastica, Delle Strutture e dei Servizi, Legambiente Onlus. 2018. Available online: https:/www.legambiente.it/wpcontent/uploads/ecosistema_scuola_2018.pdf (accessed on 16 May 2020).

51. Cittadinanzattiva. Available online: https://www.cittadinanzattiva.it/comunicati/scuola/12609-sicurezza-ascuola-presentato-il-xvii-rapporto-di-cittadinanzattiva.html (accessed on 28 June 2020).

52. MIUR, Anagrafe Dell'edilizia Scolastica. Available online: https://www.istruzione.it/edilizia_scolastica/ anagrafe.shtml (accessed on 15 July 2020).

53. Fondazione Giovanni Agnelli. Rapporto Sull'edilizia Scolastica; Editori Laterza: Bari, Italy, 2019.

54. Weyland, B.; Altmann, U.S.; Galletti, A. Scuole in Movimento. Progettare Insieme tra Pedagogia Architettura e Design; Franco Angeli: Milano, Italy, 2019.

55. Weyland, B.; Attia, S. Progettare Scuole tra Pedagogia e Architettura; Guerini e Associati: Milano, Italy, 2015.

56. Woolner, P. School Design Together; Routledge: New York, NY, USA, 2015.

57. Hille, R.T. Modern Schools: A Century of Design for Education; Wiley: Hoboken, NJ, USA, 2011.

58. Nair, P.; Fielding, R.; Lackney, J. The Language of School Design: Design Patterns for 21 Century Schools; Designshare: Minneapolis, MN, USA, 2013.

59. Dudek, M. Architecture of Schools: The New Learning Environments; Architectural Press: Oxford, UK, 2000.

60. Thayer-Bacon, B. Maria Montessori, John Dewey, and William H. Kilpatrick. Educ. Cult. 2012, 28 , 3-20. [CrossRef]

61. Haskins, C. The Montessori Method. J. Unschooling Altern. Learn. 2010, 4, 40-57.

62. Piaton, G. La Pensée Pédagogique De Célestin Freinet; Privat: Toulouse, France, 1974.

63. Lippman, P. Evidence-Based Design of Elementary and Secondary Schools: A Responsive Approach to Creating Learning Environments; Wiley: Hoboken, NJ, USA, 2010.

64. Serreli, S.; Calidoni, P. Citta' e Formazione; Hoepli Editorei: Milano, Italy, 2018.

65. Parsons, T. The school class as a social system: Some of its functions in American Society. Harv. Educ. Rev. 1959, 29, 297-318.

66. Dovey, K.; Fisher, K. Designing for adaptation: The school as socio-spatial assemblage. J. Archit. 2014, 19, 43-63. [CrossRef]

67. Michelucci, M. Prospettive Storiche E Problemi Attuali Sull'educazione, Studi In Onore Di Ernesto Cadignola; La Nuova Italia: Florence, Italy, 1960.

68. Torino fa Scuola. Available online: https://www.torinofascuola.it/ (accessed on 15 June 2020). 
69. Troisi, R.; Alfano, G. Towns as Safety Organizational Fields: An Institutional Framework in Times of Emergency. Sustainability 2019, 11, 7025. [CrossRef]

70. Lucarelli, M.T.; Pennestrì, D. Gli edifici scolastici e l'indoor air quality: Procedure diagnostiche e criteri di intervento/School buildings and indoor air quality: Diagnostic procedures and criteria for intervention. Techne J. Technol. Archit. Environ. 2015, 9, 299-306.

71. Checchi, P.; Marcetti, C.; Meringolo, P. La Scuola E La Città; Polistampa: Reggio Emilia, Italy, 2010.

72. Coppino, M. Legge 3961 del 15 luglio 1877-Regolamento per la Legge Sull'istruzione Scolastica. Available online: https:/www.icpiazzaforlanini.edu.it/wp-content/uploads/2015/07/Legge_Coppino1.pdf (accessed on 2 September 2020).

73. Grimoldi, A.; Landi, A.G. Structural Problems in Italian School Buildings of the Late Nineteenth Century; Research Paper; Politecnico di Milano: Milan, Italy, 2014.

74. Terragni, G. Asilo D'infanzia per il Rione Sant' Elia Como, 21 Maggio Xiv; Tomarin: Como, Italy, 1936.

75. Kirkpatrick, J. Montessori, Dewey, and Capitalism: Educational Theory for a Free Market in Education; TLJ Books: Claremont, CA, USA, 2008.

76. Catarci, M.; Susi, F. Scuola, Società, Politica, Democrazia. Dalla Riforma Gentile ai Decreti Delegati. Roma: Armando. J. Educ. Cult. Psychol. Stud. 2012, 3, 231-234.

77. Cataldi, S. Public Sociology and Participatory Approaches. Towards a Democratization of Social Research? Qual. Sociol. Rev. 2014, 10, 152-172.

78. Palanti, M. Scuola al Lido di Roma. Progetto dell'architetto Ignazio Guidi. Architettura 1934, XII, $623-625$. Available online: http://www.casadellarchitettura.eu/inglese/index.php?do=fascicoli\&idFascicolo=360\& idRiviste $=5$ (accessed on 4 May 2020).

79. Rogers, E.N. Dramma di una scuola. Casabella Contin. 1960, 245, 142-150.

80. D.P.R. 1 dicembre 1956, n. 1688. Approvazione di Nuove Norme per la Compilazione dei Progetti di Edifici ad Uso Delle Scuole Elementari e Materne. Available online: http://www.edizionieuropee.it/LAW/HTML/15/ zn38_08_002.html (accessed on 4 May 2020).

81. Ministero della Pubblica Istruzione. Servizio Centrale per l'Edilizia e l'Arredamento della Scuola. In Scuole Minime: Studi, Schemi e Progetti; Stabilimenti tip. E. Ariani e L'arte della stampa: Florence, Italy, 1953.

82. Legge 24 Settembre 1971, n. 820, (in GU 14 October 1971, n. 261). Norme Sull'ordinamento Della Scuola Elementare e Sulla Immissione in Ruolo Degli Insegnanti Della Scuola Elementare e Della Scuola Materna Statale. Available online: https://www.edscuola.it/archivio/norme/leggi/l820_71.html (accessed on 4 May 2020).

83. Domusweb. Italy in the 1970s: School Architecture and its Conceptual Territory. In Proceedings of the 4th Istanbul Design Biennial Architecture, Istanbul, Turkey, 22 September-4 November 2018; Available online: https://www.domusweb.it/en/events/istanbul-design-biennial/2018/09/17/italy-in-the1970s-school-architecture-and-its-conceptual-territory.html (accessed on 4 May 2020).

84. D.M. 21 Marzo 1970, “Norme Tecniche Relative All'edilizia Scolastica, ivi Compresi gli Indici Minimi di Funzionalita' Didattica, Edilizia ed Urbanistica, da Osservarsi Nella Esecuzione di Edilizia Scolastica". Available online: https://www.gazzettaufficiale.it/eli/id/1970/06/01/1314Q001/sg (accessed on 2 March 2020).

85. D.M. 18 Dicembre 1975, Norme Tecniche Relative all'edilizia Scolastica, ivi Compresi Gli Indici Minimi di Funzionalita' Didattica, Edilizia ed Urbanistica, da Osservarsi Nella Esecuzione di Edilizia Scolastica. 2 February 1976, n. 29. Available online: http://anagrafeediliziascolastica.regione.marche.it/mappla/ documentiedilizia/DM_18121975.pdf (accessed on 2 March 2020).

86. L.R. 05 Settembre 1972, n. 8 (1), Norme per L'esercizio Delle Funzioni di Competenza della Regione Lazio in Materia di Urbanistica e di Assetto del Territorio (2). Available online: http://www.consiglio.regione.lazio.it/ consiglio-regionale/?vw=leggiregionalidettaglio\&id=7083\&sv=vigente (accessed on 4 May 2020).

87. De Micheli, L.; Campanini, N.; Ciaffi, D.; Facilla, F.W.; Giuffrè, R. Piano Di Zona 167 di Rome; Comune di Rome: Rome, Italy, 1980.

88. Inaugurate a Torino le nuove Fermi e Pascoli: Qui Nasce la Scuola del Futuro, 12 September 2019. La Stampa online. Available online: https://www.lastampa.it/torino/2019/09/12/news/torino-fa-scuoladebuttano-i-nuovi-istituti-hi-tec-1.37449450 (accessed on 20 July 2020).

89. Zucconi, M.; Ferlito, R.; Sorrentino, L. Simplified survey form of unreinforced masonry buildings calibrated on data from the 2009 L'Aquila earthquake. Bull. Earthq. Eng. 2018, 16, 2877-2911. [CrossRef] 
90. DL 17 ottobre 2016, n. 189, DL 9 Febbraio 2017, n. 8, Nuovi Interventi Urgenti in Favore Delle Popolazioni Colpite Dagli Eventi Sismici del 2016 e del 2017. Available online: https://www.gazzettaufficiale.it/eli/id/ 2017/02/09/17G00021/sg (accessed on 4 May 2020).

91. Allegato 1-Elenco dei Comuni Colpiti dal Sisma del 24 Agosto 2016-ai Sensi del Comma 13 bis dell'art.48 e Dell'allegato 1 del Decreto Legge 186/2016, Convertito Dalla Legge 229 del 15 Dicembre 2016, Allegato 2-Elenco dei Comuni Colpiti dal Sisma del 26 e del 30 Ottobre 2016-ai Sensi del Comma 13 bis dell'art.48 e dell'Allegato 2 del Decreto Legge 186/2016, Convertito Dalla Legge 229 del 15 Dicembre 2016, Allegato 2 bis-Elenco dei Comuni Colpiti dal Sisma del 18 Gennaio 2017-ai Sensi dell'art. 18-Undicies e Dell'allegato 2 bis del Decreto Legge 8/2017, Convertito Dalla Legge 45 del 7 aprile 2017. Available online: https://www.sara.it/fileadmin/user_upload/Documenti/Libero_domani/elenco_comuni_ colpiti_da_sisma_27_luglio_2017.pdf (accessed on 4 May 2020).

92. Scuola in Chiaro. Available online: https://www.miur.gov.it/-/scuola-in-chiaro (accessed on 26 May 2020).

93. Technological Research Area, Group of Research on Educational Spaces. INDIRE, Manifesto Learning space 1 + 4. 2018. Available online: http://www.indire.it/wp-content/uploads/2016/03/ARC-1602-ManifestoInglese_LOW.pdf (accessed on 4 May 2020).

94. Charleson, A. Seismic Design for Architects; Architectural Press, Elsevier: Oxford, UK, 2018; p. 96.

(C) 2020 by the authors. Licensee MDPI, Basel, Switzerland. This article is an open access article distributed under the terms and conditions of the Creative Commons Attribution (CC BY) license (http://creativecommons.org/licenses/by/4.0/). 